\title{
THE CENTENARY OF THE COMMUNIST PARTY OF CHINA, MAJOR DEVELOPMENTAL ACHIEVEMENTS AND THE NEW BLUE PRINT
}

\author{
Sheriff Ghali Ibrahim and Aliyu Ahman Pategi \\ Department of Political Science and International Relations, University of Abuja; Nile \\ University of Nigeria
}

Email: sherfboy@yahoo.com; Phone: +234-7063372013

Cite this article:

Sheriff G.I., Aliyu A.P. (2021), The Centenary of the Communist Party of China, Major Developmental Achievements and the New Blue Print. Journal of Advanced Research and Multidisciplinary Studies 1(2), 1-9. DOI: 10.52589/JARMSZUDVKFCA.

\section{Manuscript History}

Received: 29 June 2021

Accepted: 27 July 2021

Published: 11 Aug 2021

Copyright $\odot 2020$ The Author(s). This is an Open Access article distributed under the terms of Creative Commons AttributionNonCommercial-NoDerivatives 4.0 International (CC BY-NC-ND 4.0 ), which permits anyone to share, use, reproduce and redistribute in any medium, provided the original author and source are credited.
ABSTRACT: This paper examines the 100 years existence of the Chinese Communist Party (CCP) since its formation in 1921 in the city of Shanghai. The significance of the CCP is also examined because it drives the policies of the Chinese People's Republic of China. It dominates the economy and controls all the state institutions. The analysis of the development trajectory of the Chinese state in the last 100 years is examined along with its major developmental achievements. The paper examines related literature from library research using descriptive method. The political party and Marxist theories are the theoretical frameworks used in examining the development milestones. The finding shows that China has emerged as the second most dominant economy in the world and is gearing towards overtaking the United States' economy in all areas. This paper concludes that the developmental achievements of the People's Republic of China was made possible by the painstaking, diligent and careful central planning of adopting the Marxist, socialist and mixed economy approach to the development of China. Finally, the paper recommends that despite all these successes recorded by transforming China and developing its economy through the careful guidance of the party, there remains a lot of challenges that its leaders must address before its continued growth gets undermined.

KEYWORDS: Centenary; Communist Party; China; Blue Print; Achievements; Socialist. 


\section{INTRODUCTION}

China historically had two political parties but contemporarily, it has multi party cooperation with various political organisations participating in the political journey of the country. The hitherto major political parties were the Chinese Communist party (CCP) and the Kuomintang, where the former defeated the latter which escaped to the Strait of Taiwan. Today, the CCP is the founding and only governing political party in China, having driven out the Kuomintang (KMT) in 1949 from mainland China to Taiwan following the Chinese civil war. The CCP was founded in 1921 in Shanghai with the help of the Soviet Union under Lenin (Steiner, 1951). The CCP controls the people's liberation army and the people's armed police. It has over 91 million members and its ideology is socialism with Chinese characteristics. The CCP was officially organised on the basis of Democratic centralism conceived by Vladimir Lenin. The highest body of the party is the national Congress convened every five years.

The duties and responsibilities of the party are vested in the politburo and standing committee with the general secretary as the party leader. The president and chairman of the Central Military Commission (CMC) is the paramount leader and the current leader is Xi Jinping, elected in November 2012. Communism is the official ideology of the CCP. The People's Republic of China (PRC) prepares to celebrate the centenary of the formation of the CPC in July, 2020 which also marks China as the only major country to see positive economic growth in 2020. The Chinese economy is slated to grow by at least $6 \%$, which according to the government, the growth of the economy will promote global economic regeneration (Steiner, 1951).

The Chinese Communist Party albeit not the oldest party in the history of world politics and democratization waves as enunciated by Huntington; the party has emerged with the most felt impact in its magnitude and influence not only in China but all over the world. It is this significant influence that has allowed the party to assume prominence and increase in followership to be one of the world's political parties with the largest followership. It has about 91 million members, which is more than twice the membership of the American Republican Party with $36,132,743$. The membership of the Communist Party of China is also almost twice the membership of the American Democratic Party, nine times the Pakistan Movement for Justice Party and eight times the Turkish Justice and Development Party, among others.

Just like the political bandwagon that produced the African National Congress (ANC) in January 1912 by John Langalibalele and Isaka Seme Sol Plaatje, the Communist Party of China born in July 1921 was founded by a group of Chinese revolutionaries, who fought against the Kuomintang imperialist subjugation and for the liberation of the Chinese people. Those who midwifed the CPC are Mao Zedong, Li Dazhao, Chen Duxiu, Chen Gongbo, Tan Pingshan, Zhang Guotao, He Mengxiong, Lou Zhanglong, Deng Zhongxia, Dong Biwu, Li Hanjun, Li Da, Chen Tanqiu, Liu Renjing, Zhou Fohai, He Shuheng and Deng Enming (Sheriff, 2020).

The birth of the Communist Party was directed towards serving the people (masses) and it paved the way for a popular coinage of the People's Republic, People's Liberation Army, People's Bank and so many other things in China, signifying everything belongs to the people. The Communist Party under the leadership of the legendary Chairman Mao embarked on the Cultural Revolution that was positively aimed at moving the country forward using the cultural 
way. The CPC leaders adopted the best development model - the most rapid, fast and efficient in changing the Chinese socio-economic conditions. This was not unconnected with the dynamics of Deng Xiaoping who adopted the policy of reform and opening up in 1978. With such reforms, China was able to quickly move from an agrarian society to an industrial society, thus allowing foreign investors to domicile portfolios in the mainland. Deng Xiaoping's legacy was upheld and continued by Jiang Zemin who opened up another developmental process under the leadership of the Communist Party to drive the country to an enviable position within the world stage.

The political theory and policy, as ratified by the CPC under Jiang Zemin, contained the Three Represents for the 2003 revision of the party's constitution, as a "guiding ideology" to encourage the party to represent "advanced productive forces, the progressive course of China's culture and the fundamental interests of the people." The theory legitimized the entry of private business owners and bourgeois elements into the party. Hu Jintao, Jiang Zemin's successor as general secretary, took office in 2002. Hu introduced two main ideological concepts: the Scientific Outlook on Development and Harmonious Socialist Society.

Such is the strength of the planned Chinese economy that whatever happens to it directly impacts the entire world economy. Most western economies are witnessing negative growth while that of China continues to thrive even during the heydays of the COVID-19 pandemic. The Chinese Communist party is the world's largest political party next to the Indian Party; however, its achievement has dominated the world's political and economic environment and guided China as the first developing country to achieve the United Nations sustainable development goals on poverty eradication. China has also left indelible footprints through technological advancements in such areas as military power, artificial intelligence, medical research, E-commerce and infrastructure development (China Daily, 2021).

\section{LITERATURE REVIEW}

The Chinese development miracle under the leadership of the CPC has provided a learning point for other societies (China Daily, 2021). "Despite China's massive and multi ethnic population, the CPC has managed to preserve the unity and harmony of the people with approval ratings of above $90 \%$. Some of the enviable attributes that have endeared the party to the people include effective political and economic planning with clear targets and accompanying timelines. This has also facilitated resource mobilisation deployment and evaluation (China Daily, 2021). One outcome of China's historical mission has been the creation of the Communist Party of China. The past, present and plans for the future all show that the party's historical mission is China's mission. The same historical mission of the party is his responsibility for China turning China into a great modern socialist country and achieving common prosperity. Similarly, the party's historical mission is the mission of humankind; it has a responsibility to humankind in making great contributions to world peace and human developments. These are the four major responsibilities, the four major missions and the four major contributions of the Communist Party of China (Angang, 2016). 
It is the verdict of Joe (2021) that as the CCP's 100th anniversary approaches, it appears even stronger than ever. On the one hand, the party led by Xi Jinping has fared comparatively well in containing the Coronavirus pandemic and increasing Chinese citizens' trust in government. From another perspective, what helped the leadership overcome challenges in recent decades was an unusual combination of political control and planning with economic flexibility and experimentation.

One of the critical reasons for the successes recorded by the CCP in developing the Chinese economy has to do with "party discipline and education," where the CCP's membership structure reflects how it has changed. In 2019, 50.7\% of members held an academic degree while the proportion of workers and peasants sank to $34.8 \%$ (Joe, 2021). Another critical success factor of the CCP is its control of China's military known as the People's Liberation Army. It has been planned that during this centenary celebration, the Red Army will have pride of place. "The display will also be an evidence of the military's absolute loyalty to the party" (Joe, 2021). The 100th anniversary celebration is seen as an opportunity for the president, who also holds the title of CCP general secretary, to present himself as a transformative figure on the same part with Mao Zedong” (Joe, 2021).

\section{Theoretical Framework}

The political party theory and the Marxist socialist theories are adopted for this essay. Political scientists have generally conceptualised parties as intermediary institutions. Demands emanating from groups are channelled through parties, which have an internal logic and organisation of their own (Nolan, 2018). Just as political parties are central to Democratic governments, so also is the CCP central to the Marxist/Socialist People's Republic of China. There are comparative differences on how political parties have aided development in both capitalist nations and socialist nations. In socialist nations like China, the political party is central to all government planning, control of the economy, military and the cultural direction of the society as a whole (Sigmund, 1954).

According to the Marxist theory, "a Communist Party is a political party that seeks to realise the social and economic goals of communism" (Sigmund, 1945). The Communist Party is the vanguard party that guides the political education and development of the working class (proletariat). As the ruling party, the Communist Party exercises power through the dictatorship of the proletariat. In China, the CCP directs the developmental aspirations of the People's Republic of China in all spheres of development. It decides policies and its implementation. It controls the economy, the military and all coercive forces in China. In short, the CCP is the engine room of the Chinese cultural, social, political, economic and military developmental agenda.

\section{FINDINGS AND DISCUSSIONS}

Sheriff (2020) assert in his essay that with "the way China is moving it is the largest economy today based on purchasing power parity even though China's GDP per capita is approximately $1 / 5$ of the United States, and if China's reforms are drastically implemented, China will make a substantial catch up." It is also pertinent to note that China is the world's second largest economy considering the global nominal GDP comparison (IMF, 2014) and China remains the world's major fastest growing economy in the world, accounting for $10 \%$ growth rate for 
over thirty years (IMF, 2013). The above-mentioned achievements are the results of the Communist Party's commitment to developing the People's Republic.

The growth of China's economy has been justified by various indices and manifestations as China maintains an economic status of the largest manufacturing economy of the world, the largest trading nation of the world, the largest exporter of goods, and world's second largest importer of goods and services. China is said to be the largest consumer market in the world today (Sheriff \& Farouk, 2020).

The reforms of China therefore have shaped the nation to be a communist state with Chinese characteristics. This is not a purely Marxist communist or socialist state as envisaged by Karl Marx or Vladimir Lenin. China is not a capitalist state but a mixture of communism, socialism and market economy driven by the opening up policy. What then are the development achievements of the People's Republic of China under the guide of the CCP? Since its founding a century ago, the CCP has steadily led the Chinese people towards the dream of national rejuvenation. The Chinese civilization is over 4000 years of continuity; they have managed to overcome scientific and technological backwardness and match the greatest world powers over the period, due to the leadership of the Communist Party (Sheriff, 2020).

China has the most people being trained in engineering, mathematics, and science and information technology. This achievement has enabled the country to become the second largest economy and the largest exporter in the world (China Daily, 2020). China has built a sophisticated defence system and an aerospace programme. In 2020, they became the first country to land a probe on the far side of the moon.

The People's Republic of China has developed the leading 5G technology and holds the patents in artificial intelligence. China also leads the high-speed train sector building for 10 years - a network that exceeds the sum of all other countries lines (Sheriff, 2020).

Today, China has managed to eradicate extreme poverty after 40 years of reform and opening up - one of the most outstanding achievements in human history. China was the first country to be hit hard by Coronavirus and COVID-19 pandemic, but it managed to contain it immediately. Its economy was the only one amongst the G20 economies of the world to grow in 2020. It also emerged as a major producer of COVID-19 vaccines to contain the virus. When looking for the reasons for China's success, two answers can be found: the determination and resilience of the Chinese people and the organisational capacity of the Communist Party of China (China Daily, 2021). There was revolutionary consciousness advanced with the creation of the CPC in 1921 when Marxist ideas and the Russian revolutions success excited the struggle against imperialism, factionalism and corruption that had weakened the country (Sheriff, 2020).

The great victory obtained on October 1, 1949 was achieved after much struggle and perseverance, not only against reactionary nationalists but against Japanese militarist imperialism. All these were achieved after a difficult and costly war in the Korean peninsula between 1950 and 1953. Also, another difficult era for the CCP was the "great leap forward" (1958 to 1960) and the era of the Cultural Revolution (1966 to 1976) but they both served as beneficial experiences for the later phase in 1978 of the reform and opening up (China Daily, 2021). 
The CCP, under the leadership of Mao, withstood international pressure, divided the rural land among villagers, contributed to women's autonomy, organised a campaign for mass education, created a heavy industrial sector and built a strong defence capacity. Under Deng's leadership, the CCP shifted development focus to the fight against backwardness and poverty. His era saw the reintegration of the Chinese economy back into the world economy. Jiang Zemin and Hu Jintao persevered on Deng's path, strengthened the economy and laid the foundations for the continuous improvement of the Chinese people's wellbeing. The present leader, Xi Jinping is addressing new challenges faced by China and taking China's share of world's responsibilities as its main international relations goal. There have been some specific infrastructural milestones recorded by China over the period, and these include but are not limited to the following:

Firstly, we have the Three Gorges Dam, the world's biggest hydro power project in terms of electricity production. Secondly, we have China's south to north water diversion project, the biggest water transfer project in the world which benefits over one million people. Thirdly, the world's longest pipelines, the giant West East gas pipeline project with a length of 1704 kilometres, and the world's highest railway, which is the Qinghai- Tibet railway with its highest point reaching an altitude of 5072 metres. There is also the world's longest cross sea bridge, the 55-kilometre-long Hong Kong Zhuhai, Macau Bridge. And in addition is the world's longest underwater tube tunnel, a 6.7-kilometre tunnel, to name but a few. From 1949 to 2018, the country's transport network saw notable expansion. By 2018, the total railway operation mileage reached 131,000 kilometres. Inland waterways have expanded $72.7 \%$ to 127,000 kilometres in miles, while civil aviation flights routes surged 734 times from the figure in 1950 to 8.38 million kilometres in 2018. Telecom networks also reported fast expansion ... China's mobile broadband network users topped 1.31 billion in 2018 .

Another major achievement of PRC is the Belt and Road Initiative (BRI). It aims to connect Asia with Europe, Africa and beyond. Ports, railways, highways electricity, aviation and communication infrastructure development along the belt and road have been effectively upgraded with better-than-expected results (Global Times, 2019).

Every societal purpose is development. Dudley Seers believes that development takes place when a country experiences a reduction or elimination of poverty, inequality and unemployment. The CPC has been focusing on fighting unemployment, raising the standard of living and workers' wages. It is in line with the above that we look at the trajectories of unemployment statistics in advanced societies, for example the United States having 6.2\%, United Kingdom with 7.5\%, France having 7.9\% and only China with the least unemployment record despite its huge population at just 5.3\%. This shows that the Communist Party of China should be given some accolades in its relentless efforts in dealing with unemployment in China, which shows that the country is progressing (Seers, 1979).

The development of a country is also considered looking at the level of income inequality among the citizenry (Seers, 1979). Considering the Gini Coefficients of income inequality, the United States has $41.4 \%$ records of inequality while China has $38.5 \%$. This shows that there is perfect equality in China and perfect inequality in the U.S. based on the Gini Coefficients.

On poverty reduction, over the 4 decades, China has been able to lift more than 700 million people out of poverty, contributing more than 70 per cent of global poverty reduction. By the end of 2020, nearly 100 million impoverished rural dwellers had escaped poverty since the 
18th National Congress of the CPC in 2012, and all 832 national level poverty-stricken countries had shaken off poverty. Despite the COVID-19 impacts in 2020, China succeeded in removing the remaining 52 countries in South Western China and western regions from the poverty list as scheduled in 2020 (Xinhua News, 2021).

With the coming of President Xi Jinping as the General Secretary of the CPC and Core of the Communist Party, many reforms have taken place and China has been promised prosperity. Xi upheld the principles of reform in his 'Four Comprehensives' (SI GE QUAN MAIN) of: making China a moderately prosperous society, deepening reform, party discipline and deepening rule of law. These principles are foundations upon which all civilized societies should build a prosperous society and with the 13th Five-Year Plan (2016-20), China will primarily realize the goal of building a moderately prosperous society in all respects, which is the first of the two centenary goals laid down to mark the centenary of the Communist Party of China (Xinhua News, 2021).

The fifth plenary session of the 19th CPC Central Committee convened in Beijing during October, 26-29 2020, was therefore a milestone meeting where decisions were made on the next five-year plan for economic and social development and also set more long-distance targets till 2035. The blueprint of the 14th five-year plan (2021-25) decided on at the plenum sets forth the concepts, principles and tasks to guide the country's economic and social development in the next five years. Additionally, it will pave the way for the Second Centenary goal of building a modern socialist country to mark 100 years of the People's Republic of China, which was founded on October 1, 1949 (Xinhua News, 2021).

In 2017, the 19th CPC National Congress drew up a two-stage long-term development plan. In the first stage from 2020 to 2035, the task is to build on the foundation created by a moderately prosperous society with 15 more years of efforts to ensure socialist modernization is basically realized. In the second stage, from 2035 to 2050, having basically achieved socialist modernization, the task is to ensure that in another 15 years, China becomes a modern socialist country that is prosperous, strong, democratic, culturally advanced, harmonious and beautiful. Therefore, the plenum also charted out the goals for the next 15 years that will be the first of the two stages in China's new journey to socialist modernization.

The innovations decided on at the plenum will help to break down deep-seated institutional barriers and deepen reform in important areas with greater courage and more measures. In the new development pattern, the domestic and international markets will boost each other, with the domestic market as the mainstay. In the future, China will open up further and contribute to international development in a more inclusive manner. The development achieved by the CPC is unprecedented and uncountable in human development, science and technology, economic and social fields, and ultimately democratic development (Xinhua News, 2021). 


\section{CONCLUSION AND RECOMMENDATIONS}

Today, China has become a very strong superpower in international affairs. This was achieved by the careful planning of the Chinese Nation by the CCP. The PRC owns $20.8 \%$ of all foreign owned U.S. Treasury securities - from a country that could barely feed its people not too long ago to an economic giant. The opening up policy and the gradual privatisation of state assets, together with the centrally planned nature of the economy, gradually led to the Chinese economic successes. It succeeded in shifting towards a market economy.

Gradual government reforms have kept the country's economic growth steady and consistent. China has also emerged as a major player in international politics and this is a testament to the legitimacy and respect the CCP has had abroad.

In 2008, the Chinese successfully hosted the Beijing Summer Olympics where they hosted 11,028 athletes from 204 nations competing in 28 sports and 302 events, spending over 40 billion Yuan. This was a spectacular event that showcased the arrival of China as a global power. Equally in 2010, the Shanghai world exposition also caught the attention of the world not only enhancing the city's global status but also bringing in abundant economic opportunities. However, despite these positive strides, the People's Republic of China is faced with a number of challenges that its leaders must address quickly before its future growth is undermined. These challenges include its human rights record and crackdown on dissidents. The South and East China Seas territorial claims are straining China's diplomatic relations with its neighbours. A diplomatic solution to these crises would improve international relations within South East Asia.

Another contentious issue that the central government must address is the crisis within the housing sector where there is a boom that has brought resentment from the working class; they are being left out. The wide disparity between the Chinese rich and poor politically and income wise is a potential ticking time bomb. With all these challenges, the CCP must continue its modernisation drive in government reform, science and technology, and education, and create a market economy. Finally, the 5th generation of Chinese leaders in CCP must speak with one voice and unite all the groups within its fold.

\section{REFERENCES}

Adhere, C. (2021). Global: China Daily.com.cn: Impressive Achievements of CCP offers lessons for other nations. June 17.

Angang, H. (2016). Mao and the Cultural Revolution (Volume 1). Honolulu: Silkroad Press.

Chan, K. W. (2007). "Misconceptions and Complexities in the Study of China's Cities:

Definitions, Statistics, and Implications" (PDF). Eurasian Geography and

Economics. 48 (4): 383-412. doi:10.2747/1538-7216.48.4.383.

China Daily (2021) Poverty Reduction: China's Experience. May, 23.

Global Times (2019). Infrastructure has Brought China Forward over the Last 70 years. May, 26.

IMF (2013), “People's Republic of China Article IV Consultation—Staff Report,” IMF Country Report 12/195 (Washington).

Jeo, E. (2021). The week Inside the plans for the Chinese Communist Party's 100 Anniversary. Kaplan News, June 18. 
Nis, G. and Claudia, W. (2021). The powerful centenarian: China's communist party turns 100. Global News, June 10.

Nolan, M. and Schickler, C. (2018). On the Theory of Parties, Princeton, University Press.

Seers, D. (1969). The Meaning of Development. International Development Review 11(4):34.

Sheriff, G. I. (2020). China-Phobia and the Decline of American Empire. Blue Print, April, 22.

Sigmund, N. (1954). Review towards a Theory of Political Parties. New York, Praegers.

Steiner, A. H. (1951), Current 'Mass Line' Tactics in Communist China, in: The American Political Science Review, 45, 2, June, 422-436.

Xinhua News (2021). Poverty Alleviation: China's Experience and Contribution. Accessed on June 27. http://www.xinhuanet.com/english/2021-04/06/c_139860414.htm 